\title{
The Diversion for Children Who are Doing Crime of Theft
}

Sudarwin ${ }^{1}$

${ }^{1}$ Faculty of Law, Universitas Indonesia, Indonesia sudarwin.sh@gmail.com

\begin{abstract}
Introduction to The Problem: This article is based on the problems related to the handling of children in conflict with the existing law so far that it is still not free from treatments that are oriented towards depriving independence. The deprivation of liberty in question even occurs in cases of theft that actually can be resolved through restorative justice through diversion.
\end{abstract}

Purpose/Objective Study: The aim of this research is to find out how the actual regulation of diversion related to criminal acts of theft in Law No. 11 of 2012 concerning the Juvenile Justice System and other related regulations, and how the implementation of diversion concept, especially against criminal theft.

Design/Methodology/Approach: This article uses descriptive normative writing methods, namely explaining the facts related to the implementation of diversion in a criminal act of theft, how the arrangements and author's suggestions for the diversion arrangement in the future. The source of the data used is secondary data sources, namely, data sources obtained from literature studies, such as books, journals, newspaper articles, and the internet.

Findings: There are problems in Law No. 11 of 2012 concerning the Juvenile Justice System, where diversion provisions are limited only to crimes under 7 (seven) years, which have made many child offenders end up in the deprivation of liberty decisions. Then, the provisions of Article 9 Paragraph (2) of the act that eliminates or does not involve victims in diversion efforts whose losses are below the provincial minimum wage have harmed the concept of restorative justice. So, there needs to be some improvement such as the legislation governing diversion should no longer be limited by providing requirements regarding the implementation of diversion based on the number of penalties but the criminal acts that can be regulated by police regulation, and the diversion should be carried out by bringing together perpetrators and victims without exception.

Paper Type: Research Article

Keywords: Children; Crime, Restorative Justice; Diversion; Theft

\section{Introduction}

Children are an integral part of the continuation of the life of the nation and the state, because children are the next generation who will continue the leadership relay, realize sustainable development and prosperity for the Nation and the country. In achieving all this, children have an essential role in determining how the fate of the 
nation and state in the future, by which the community and the country need to be present to guarantee various things to provide the fulfilment of children's rights, including providing the best education and keep away from different wrong treatments that can interfere with child development.

Child protection efforts in Indonesia are guaranteed through the existence of Law No. 23 of 2002, as amended by Law No. 35 of 2014. In the considerations of letters $c$ and $\mathrm{d}$ of this law, it is stated that the existence of this law is due to seeing children as budding, potential, and the younger generation to succeed the ideals of the national struggle which have a strategic role and have characteristics and traits specifically to ensure the continued existence of the nation and state in the future. So that for each child to be able to assume these responsibilities, he needs to get the broadest opportunity to grow and develop optimally, both physically, mentally and socially, and have a noble character, protection efforts are needed to realize the welfare of children by providing guarantees for fulfilment of their rights and the existence of treatment without discrimination, includes children who are criminals.

The legal basis for the protection of the rights of children who become perpetrators of crime, in this case, called children in conflict with the law, is Law No. 11 of 2012 concerning the Juvenile Justice System (SPPA Act). The presence of this law is one of the efforts to protect children's rights, which is often overlooked in criminal justice processes in cases committed by children. Children often experience humiliation, harassment, violence, discrimination, and their freedom is robbed at various levels of the criminal justice system, including in correctional institutions.

In Corrections Institutions, many children deprived of their liberty are placed together with adult perpetrators, even though it is denied, or it will not adversely affect the growth of the child later. Children who are in a Corrections Institutions environment face a restrictive environment, associating with prisoners with various types of crimes, and if free, they will get the stigma of unfortunate children who are difficult to be rehabilitated throughout their lives.

Placement of children with adults in various Corrections Institutions occurs because of the increasing number of juvenile cases that end with deprivation of independence, especially coupled with other issues, namely the inadequacy of existing child corrections institutions, which in the SPPA Law is called the Special Guidance Institution for Children (LPKA). At present, there are only 33 LPKA in several provinces in Indonesia, while child offenders in areas that do not yet have LPKA are placed in Detention Centers and Corrections Institutions (Kirom, 2018).

The Indonesian Child Protection Commission (KPAI) notes that even in LPKA, children are not free from violence. During 2011-2018 there were 26.8\% of child prisoners in LPKA who were victims of violence in the form of physical, psychological, and sexual abuse (Bernie, 2019). This number could only be a small fraction of the actual number because there are still many cases that are likely not reported. Various 
criminal cases involving children, so that they have to deal with the law, are actual and factual problems and also as a social and criminal phenomenon that has given rise to concern among parents, the community, and law enforcement (Sosiawan, 2017).

Various problems that arise in children deprived of liberty naturally raise the question, is deprivation of freedom as a mechanism for resolving cases of children in conflict with the law is correct or not? In the SPPA Act, it is emphasized that deprivation of independence should be a measure of last resort (ultimum remedium) and as a way to prevent children from depriving independence, diversion must be sought as an effort to resolve cases through the perspective of achieving justice by restoring conditions as previously known as the restorative justice principle (restorative justice).

Restorative justice is a concept in which all parties involved in a particular crime together seek a solution in dealing with events after the emergence of the crime and how to overcome its implications in the future. The diversion itself is a form of restorative justice. One of the benefits of this mechanism is that the child will be able to be more directly responsible to the victim for what the child has done. Diversion is needed to achieve peace between victims and children, resolve cases outside the judicial process, prevent children from deprivation of liberty, encourage communities to participate, and instil a sense of responsibility to children.

The existence of this mechanism is expected to provide three benefits; namely, the first child who commits a crime can avoid the adverse effects of detention and imprisonment. Secondly, the settlement will be more beneficial for the recovery of victims and thirdly increase public awareness through community leaders to guide rather than stigmatize children who commit crimes. The purpose of the implementation of the juvenile criminal justice system is not merely aimed at imposing criminal sanctions on child offenders, but rather is focused on the responsibility of perpetrators against victims of criminal acts (Ananda, 2018).

According to Peter C. Kratcoski, as quoted by Hambali (Hambali, 2019), there are three types of implementation of the diversion concept, namely: (1) Social control (social control orientation), which is where law enforcement officials surrender the perpetrators in the responsibility of supervision or observation of the community, (2) Social services by the community to the perpetrators (social service orientation), namely carrying out functions to supervise, interfere, improve, and provide services to the perpetrators and their families, (3) As a process of restorative justice or balanced (restorative justice orientation), which is protecting the community, giving the opportunity for the perpetrators to be directly responsible to the victims and the community by making a mutual agreement between the victims of the perpetrators and the community. 
At the international level, it has been intended that the main objective in the administration of the juvenile justice system is for the welfare of the child. That rule is stated in the United Nations Regulation, in the United Nations Standard Minimum Rules for the Administration of Juvenile Justice (SMRJJ) or The Beijing Rules, that the purpose of juvenile justice (aims of juvenile justice) is as follows (Wahyudi, 2011): "The Juvenile Justice System shall emphasize the well-being of the juvenile and shall ensure that any reaction to juvenile offenders shall always be in proportion to the circumstances of both the offenders and offence." It means that the main focus of the juvenile justice system is to keep children away from the use of criminal sanctions that are merely punitive or retributive, and the principle of proportionality also needs to be put forward by paying attention to how the child's circumstances. In the development of criminal law itself, there has been a paradigm shift in the philosophy of juvenile justice, which initially was retributive justice, then changed to rehabilitation, then finally to restorative justice (Purnama et al., 2016).

Although there are rules that allow diversification of the crime that is threatened with seven years imprisonment, there are still many decisions against child perpetrators, especially in the crime of theft, which even ends in prison. The Diversion is needed for children who are doing crime of theft to protect more child from the deprivation of liberty, whereas in many cases actually can be sought to be resolved using a diversion mechanism. One interesting decision was Decision No. 103/Pid.Sus-Anak/2018/PN Plg where the child offender, in this case, is entangled in Article 363 paragraph (1) of the Criminal Code and sentenced to criminal for 1 (one) month 15 (fifteen) days in LPKA for the theft of a helmet, whereas the ruling has stated that between the child and the victim have reconciled, so the case should be resolved through diversion.

Based on the above background, the problem to be discussed in this study is related to how the concept and implementation of diversion of children in conflict with the law in criminal theft by Law No. 11 of 2012 concerning the Juvenile Justice System and other related regulations and how should the concept and implementation of future diversion be carried out against the theft of crimes committed by children?

\section{Methodology}

The research method is normative legal research, which is intended to study and examine various legal norms in Law Number 11 of 2012 as well as provisions in other legislation that relate to the themes discussed. Presentation of research results by a descriptive method that is by describing the application of diversion based on the provisions of Law No. 11 of 2012 concerning the Juvenile Justice System and other related regulations, then linked to theft crime and the rules governing it. Data sources used are secondary data sources, namely, data sources that originate from books, journals, and other related documents. 


\section{Results and Discussion}

\section{Concept and Implementation of Diversion for Children in Theft Crimes Based on Law Number 11 of 2012 concerning the Juvenile Justice System (SPPA Law) and Other Related Regulations}

The element of responsibility is an essential element in handling every crime. A person is brought before a criminal court whose purpose is to prove whether an act committed can be justified or not. A person can be held accountable for his actions if he has a mistake so that his works should be harmed to that person (Wahyudi, 2011). The mistake is that the criminal maker can be denounced because, in terms of his actions, he can do otherwise if he does not want to do the act.

Making a person accountable by the provisions of the criminal law does not only mean that it is lawful to impose a crime against that person, but it is considered that it is indeed in place to hold him responsible for the criminal act he committed. In the case of children, the element of responsibility is so important. It is because children, according to their age, are deemed incapable of responsibility, so it is a question whether a child can be imposed criminal or not.

The granting of a crime, especially in the form of deprivation of liberty, is undoubtedly contradictory if it is applied to children, seeing that the actions of children have specific characteristics that are different from adult offenders; therefore, a special approach is needed. It was expressed in the Convention on the Rights of the Child as cited by Sri Rahayu (Rahayu, 2015), which expressly states that: "In all actions concerning children, whether undertaken by public or private social welfare institution, courts of law, administrative authorities or legislative bodies, the best interest of the child shall be a primary consideration."

The criminal justice system of children is different from adults. It is due to the immature way of thinking of children, besides that in the criminal justice process, it is expected that the child's psychological development is not disturbed, both spiritually, physically, and socially. Children have rights categorically different from the rights of adults, and this is because children are very vulnerable to violence, abuse, and exploitation (Rochaeti, 2015). In other words, the actions given to children should pay attention to the welfare of the child so that the treatment given is not to get closer to the prison culture, where the consequences are not even better but it will be even worse for the child as it is understood that justice is essentially by treating someone or other parties according to their rights (Taufik, 2013).

The primary purpose of legal protection is to realize the welfare of children in addition to the interests of the community. However, children's attention should not be sacrificed for the benefit of the community. Two essential principles that must be considered are the principle of advancing child welfare (the promotion of the well being of the juvenile) and the principle of proportionality. 
In the case of children in conflict with the law, theft is one of the most common crimes committed. Children are often faced with trials and are convicted of the crime of deprivation of independence even though the SPPA Act has mandated to always prioritize the principles of restorative justice in every handling of juvenile cases and make deprivation of autonomy only as a measure of last resort.

Restorative justice rests on the perspective that crime is an act that violates primarily the rights of individuals as well as, of course, against the community, the state, to the interests of the victims themselves. Therefore, every violation of criminal law has four related benefits, namely for people whose rights are violated (victims of crime), society, the state, and for violators. Restorative justice is a process in which all parties involved in a crime jointly solve the problem and handle the consequences that may arise in the future (Edyanto, 2017).

Restorative Justice, according to Tony Marshall, adopted by the United Nations Juvenile Justice Working Group, is a process in which all parties related to a particular criminal act jointly solve the problem and how to deal with the consequences in the future. Then the concept of restorative justice from the United Nations Children's Fund (UNICEF) emphasizes justice that can heal, which is to restore the offenders of children, victims, and the public who are disturbed due to the crime (Kaimuddin, 2015).

Restorative justice is carried out by bringing together perpetrators and victims who indeed involve the community. During the meeting, the mediator allowed the actor to provide a clear picture of the actions he had taken. Here the victim has a better position because the state no longer represents treatment, and victims can get involved together to find the best way out of the criminal justice system.

In criminal acts of theft, an act committed by a child can be attempted to be resolved through a restorative justice mechanism, which is a diversion. A diversion is a form of legal protection provided by the State as stipulated in the SPPA Act against perpetrators and victims. It means that there are two parties protected by the state, namely the victim and also the perpetrator. Legal protection as the protection of Human Rights (HAM) that is harmed by others, and the security is given to the community so that they can enjoy all the rights provided by law.

Diversion can be given to children as long as they meet the requirements for diversion, according to the provisions in Article 7 paragraph of the SPPA Act: (1) At the level of investigation, prosecution, and examination of cases of Children in the district court must be tried diversion, (2) Diversity, as referred to in paragraph (1), shall be carried out if a criminal offence is committed: (a) threatened with imprisonment of under 7 (seven) years; and (b) is not a repeat of a criminal offence.

This provision then implies that a child cannot be adequately provided with an alternative case resolution through diversion, because this rule only limits criminal 
offences under threat of 7 (seven) years. But even so, the Supreme Court expanded the scope of children that can be diversified is also against crimes that are threatened with 7 (seven) years through Supreme Court Regulation No. 4 of 2014 concerning Guidelines for the Implementation of Diversity. In Article 3 the regulation states: "The Child Judge must seek diversion if the child is convicted of a criminal offence threatened with imprisonment for less than 7 (seven) years and also charged with an offence threatened with imprisonment of 7 (seven) years or more in the form of subsidiarity, alternative, cumulative, or combination (combined) indictment".

The existence of this provision then broadens the scope of diversion that can be done to children in conflict with the law. It means that in a crime that is threatened with seven years, the court has the authority to carry out diversion and is not at the stage of investigation or prosecution.

Criminal provisions against theft are regulated in articles 362-367 of the Criminal Code (KUHP). The exciting thing here is the provisions of Article 363 which state that: (1) Threatened with a maximum sentence of seven years: 1 . theft of cattle; 2 . theft in the event of a fire, eruption, flood, earthquake, volcano eruption, shipwreck, shipwreck, train accident, riot, rebellion or danger of war; 3 . theft at night in a house or closed yard with a house, which is carried out by people who are there unknown or unwanted by the rightful; 4 . theft committed by two or more people; 5 . Theft that to enter the place to perform a crime or to arrive at items taken is done by damaging, cutting, or climbing or by using fake keys, fake orders, or fake office clothing... (2) If the theft described in point 3 is accompanied by one of the items in items 4 and 5, then the sentence is imprisoned for a maximum of nine years.

Provisions in Article 363 of the Criminal Code for theft are punishable by imprisonment for a maximum of seven years if they are carried out in matters that can be burdensome as stated, and a maximum of nine years for the theft committed in points 1,2 or 3 and is accompanied by one of the items in items 4 and 5 of this article.

For ordinary theft itself based on the provisions of article 362 of the Criminal Code threatened with a maximum of 5 (five) years so that it can be diversified in its handling, this also includes theft with weighting in article 363 paragraph (1) of the Criminal Code, so that the diversion itself can only be made on the theft charged with these two Criminal Code articles.

\section{Recommendations for Concept and Implementation of Diversion for Children in Crime of Theft}

Decision No. 103/Pid.Sus-Anak/2018/PN Plg, the court imposed a prison sentence in LPKA for 1 (one) month and 15 (fifteen) days against a child committing an act of theft with weighting as regulated in article 363 paragraph (1) number 3 and number 4 of the Criminal Code. This decision was given for the theft of an iron fence made by a 
child along with a colleague. In the information on the decision, it was found that the child was only invited to commit theft by his colleague.

The interesting things in decision No. 103/Pid.Sus-Anak/2018/PN Plg is that there has been peace between the victim and the perpetrator based on information in matters which relieve the decision, but this case continues and is processed until the court verdict is issued. Peace itself, based on the SPPA Act, is one of the results of diversionary efforts, where if peace is achieved, there is no reason for a child to be handled through the criminal justice system.

The issue that allows the case to be subsequently not diversified is because this criminal offence is threatened with a maximum sentence of 9 years, this is based on the provisions in the crime of theft in article 363 paragraph (2) of the Criminal Code. Therefore, based on the existing arrangements, it means that it does not meet the requirements for diversion by the regulations in Article 7 paragraph (2) of the SPPA Act which only limits diversion to criminal acts that are threatened under seven years or illegal actions that are threatened with a maximum of 7 years based on Supreme Court Regulation No. 4 of 2014 concerning Guidelines for the Implementation of Diversion.

The existence of this decision shows that there are still weaknesses in the juvenile justice system in Indonesia, especially those related to handling theft of crimes. Diversion cannot be implemented, whereas in that case, diversion should be a mechanism that can be properly carried out, and children can be kept away from the punishment that can deprive their freedom and independence.

Crimes committed by children such as theft are mostly caused by the economic factors of the child's family, which are low, neglected, the influence of bad relationships, or dropping out of school. Therefore, the involvement of children as theft perpetrators certainly cannot be considered as something that is not important to study, especially if children are sentenced to imprisonment even though only theft whose object has a relatively low value (Kurnia, 2018).

The point is that the legislation governing diversion should be reformed with no longer be limited by providing requirements regarding the implementation of diversion based on the number of penalties but the criminal acts. Regarding criminal actions that can be diversified, it can be regulated in the National Police Regulation regarding guidelines for the implementation of diversion, so that the decision whether or not a diversified crime depends on an assessment by the frontline of the criminal justice system, namely the police institution. Criminal law reform is an attempt to re-orient and reform criminal law in accordance with the values of the sociopolitics, social-philosophy, and socio-cultural aspects that underlie social policies, criminal policies, and law enforcement policies (Firmanto, 2017). 
The police can also implement diversion through its discretionary authority. Discretion is the authority of the police officer to take action to continue the case or stop the case by its policies. The process of discretion takes place spontaneously, which arises in the person of a law enforcer without being planned (Ghufron, 2018).

The police can also form a special team that is trained in handling criminal acts committed by children to streamline the application of diversion so that the police can intervene directly to manage or mediate problems and mingle with the community. That way, the police can find out firsthand the issues that occur and find solutions using the restorative justice approach, which is through the diversion mechanism (Manurung, 2015).

For the law to live in the community, a law enforcement component is needed that is expected to be able to see the law and the condition of the community. Also, the form of implementation of diversion needs to be considered, one of which can be to keep children away from their environment for a certain period or even so on, because it must be understood that criminal acts committed by children are also caused by environmental influences. The psychological impact of individuals living in community life, which leads to disharmony, can form norms that apply in the society in which the individual lives.

In addition to the protection of child offenders, it is also necessary to reinforce the protection of the rights of victims in juvenile cases. In Article 9 paragraph (2) of the SPPA Act, it is mentioned: Diversion Agreement must obtain the consent of the victim and/or the victim's child, and the willingness of the child and his family, except to; (a) criminal acts in the form of violations, (b) minor criminal offences; (c) crime without victims; or (d) the loss value of the victim is not more than the value of the provincial minimum wage.

Article 9 paragraph (2) disrupts the concept of restorative justice where the perpetrators and victims should be brought together to find the best solution for both parties, but the provision of losses below the provincial minimum wage in letter $\mathrm{d}$ of the article eliminates the role of the victim in handling criminal cases children through diversion.

Losses suffered by victims can not always be assessed in nominal terms, for needy families, for example, those who work daily as street vendors, $3 \mathrm{~kg} \mathrm{LPG}$ cylinders will undoubtedly be very meaningful to their survival, so if a crime occurs where someone steals the gas cylinder then in the diversion process it is necessary to pay attention to the rights of victims who must be fulfilled and protected, for example by the perpetrators returning or replacing stolen LPG cylinders.

If the interests of victims are distinguished based on the level of loss, then it does not rule out the possibility that the community no longer believes in the law so that the potential of the victim then prosecutes the perpetrators of theft due to his 
disappointment in the criminal justice system, this is undoubtedly dangerous to child offenders. Those who become victims of criminal acts of theft when reporting to law enforcement officials, victims hope to receive protection from the state, in the form of protection of their rights as victims and also wish to receive compensation. But what happened next was the opposite; those whose losses were below the provincial minimum wage were not included in the diversion process.

The state shall guarantee and protect the human rights of its citizens based on the principle of equal rights, democracy, social justice, equality and gender justice, and anti-discrimination (Nur, 2018). Article 3 paragraph (2) of Law No. 39 of 1999 concerning Human Rights states that everyone has the right to recognition, guarantees, protection, and fair legal treatment and to obtain legal certainty and equal treatment before the law. Article 5 paragraph (1) confirms that every person is recognized as a private person who has the right to demand and obtain the same treatment and protection by the dignity and human dignity before the law. Then, Article 5 paragraph (2) states that everyone has the right to receive generous assistance and protection from an objective and impartial trial.

\section{Conclusion}

The mechanism for resolving juvenile cases with restorative justice is introduced through a diversion mechanism In Law No. 11 of 2012 concerning the Juvenile Justice System (SPPA). One crime that can use the diversion mechanism is theft. But, there are problems in SPPA Act where diversion provisions are limited only to crimes under 7 (seven) years, which have made many child offenders end up in the deprivation of liberty decisions, and the provisions of Article 9 Paragraph (2) of the SPPA Act that eliminates or does not involve victims in diversion efforts whose losses are below the provincial minimum wage have harmed the concept of restorative justice. So, the legislation governing diversion should no longer be limited by providing requirements regarding the implementation of diversion based on the number of penalties but the criminal acts. It can be regulated in the National Police Regulation regarding guidelines for the implementation of diversion.

The police, as the frontline of the judiciary, can also implement diversion through its discretionary authority, so the police can be more selective in choosing cases to be processed, especially against crimes committed by children. Police can also resolve cases of children by joining in the community, and providing solutions that are restorative so that they can give justice to both the victim and the child offender. Then, social institutions and the community are expected to be more able to participate in handling cases of children in conflict with the law. This is expected to bring out the best solutions that can be done in handling child cases, so that child offenders can be kept away from crimes that can take away their independence and endanger its safety. 


\section{References}

Ananda, F. (2018). Penerapan diversi sebagai upaya perlindungan hukum terhadap anak pelaku tindak pidana. Jurnal Daulat Hukum, 1(1), 77-86. https://doi.org/http://dx.doi.org/10.30659/jdh.1.1.\%25p

Bernie, M. (2019). KPAI: 26,8 Persen napi lapas anak alami kekerasan. https://tirto.id/kpai-268-persen-napi-lapas-anak-alami-kekerasan-ec3P

Edyanto, N. (2017). Restorative justice untuk menyelesaikan kasus anak yang berhadapan dengan hukum. Jurnal Ilmu Kepolisian, 11(3), 39-46. Retrieved from http://www.jurnalptik.id/index.php/JIK/article/download/8/5

Firmanto, A. A. (2017). Kedudukan pidana kebiri dalam sistem pemidanaan di indonesia (pasca dikeluarkannya PERPPU No. 1 Tahun 2016). Jurnal Hukum Novelty, 8(1), 1-19. https://doi.org/10.26555/novelty.v8i1.a5523

Ghufron. (2018). Pelaksanaan Diversi sebagai bentuk penyelesaian perkara terhadap anak pelaku tindak pidana. Jurnal Negara Dan Keadilan, 7(2), 1-14. Retrieved from http://riset.unisma.ac.id/index.php/negkea/article/viewFile/1610/1570

Hambali, A. R. (2019). Penerapan Diversi terhadap anak yang berhadapan dengan hukum dalam sistem peradilan pidana (diversions for children in conflict with the laws in the criminal justice system). Jurnal Ilmu Hukum, 13(1), 15-30. https://doi.org/http://dx.doi.org/10.30641/kebijakan.2019.V13.15-30

Kaimuddin, A. (2015). Perlindungan hukum korban tindak pidana pencurian ringan pada proses diversi tingkat penyidikan. Jurnal Arena Hukum, 8(2), 258-279. https://doi.org/10.21776/ub.arenahukum.2015.00802.7

Kirom. (2018). Menkum HAM targetkan pembangunan 14 penjara anak hingga 2019. https://www.merdeka.com/peristiwa/menkum-ham-targetkanpembangunan-14-penjara-anak-hingga-2019.html

Kurnia, L. C. (2018). Tinjauan yuridis terhadap kejahatan harta benda menurut pasal 365 kuhp tentang pencurian dengan kekerasan. Jurnal Lex Crimen, 7(3), 161-167. Retrieved from https://ejournal.unsrat.ac.id/index.php/lexcrimen/article/download/20014/ 19622

Manurung, D. (2015). Penerapan diversi dalam penyelesaian tindak pidana yang dilakukan oleh anak di Pengadilan Negeri Pekanbaru. Jurnal Online Mahasiswa (JOM) Universitas Riau, 2(2), 1-15. Retrieved from https://jom.unri.ac.id/index.php/JOMFHUKUM/article/view/5858/5728

Nur, M. (2018). Recommendation for authorization overlapping of placement of Indonesian fishing vessels crews abroad. Jurnal IUS Kajian Hukum Dan Keadilan, 6(1), 1-13. Retrieved from https://jurnalius.ac.id/ojs/index.php/jurnalIUS/article/view/532/pdf_62

Purnama, P. C., Krisnan, J., \& Kurniaty, Y. (2016). Pelaksanaan diversi ditingkat pengadilan berdasarkan Undang-Undang Nomor 11 Tahun 2012 Tentang Sistem Peradilan Pidana Anak. Jurnal Varia Justicia, 12(1), 222-234. Retrieved from http://journal.ummgl.ac.id/index.php/variajusticia/article/view/353/270 
Rahayu, S. (2015). Diversi sebagai alternatif penyelesaian perkara tindak pidana yang dilakukan anak dalam perspektif sistem peradilan pidana anak. Jurnal Ilmu Hukum, 6(1), 127-142. Retrieved from https://media.neliti.com/media/publications/43317-ID-diversi-sebagaialternatif-penyelesaian-perkara-tindak-pidana-yang-dilakukan-ana.pdf

Rochaeti, N. (2015). Implementasi keadilan restoratif dan pluralisme hukum dalam sistem peradilan pidana anak di Indonesia. Jurnal Masalah-Masalah Hukum, 44(2), 150-160. Retrieved from https://ejournal.undip.ac.id/index.php/mmh/article/view/11435/9653

Sosiawan, U. M. (2017). Perspektif restorative justice sebagai wujud perlindungan anak yang berhadapan dengan hukum (perspective of restorative justice as a children protection against the law). Jurnal Penelitian Hukum De Jure, 16(4), 425-438. https://doi.org/10.30641/dejure.2016.V16.425-438

Taufik, M. (2013). Filsafat John Rawls tentang teori keadilan. Jurnal Studi Islam Mukaddimah, 11(1), 41-63. Retrieved from http://digilib.uinsuka.ac.id/33208/1/Muhammad Taufik - Filsafat John Rawls.pdf

Wahyudi, S. (2011). Implementasi ide diversi dalam pembaruan sistem peradilan pidana anak di Indonesia. Yogyakarta: Genta Publishing. 